\title{
Effect of Vermicompost and Zinc on Growth, Yield Attributes and Yield of Greengram [Vigna radiata (L.)] Under Semi-Arid Region of Rajasthan
}

\author{
Anita Todawat, S.R. Sharma, Hansa Lakhran" and Hemraj \\ Department of soil science and Agricultural Chemistry, S. K. N. College of Agriculture, S. K. N. \\ Agriculture University, Jobner, Jaipur, Rajasthan 303329, India \\ *Corresponding author
}

\section{A B S T R A C T}

Keywords

Greengram,

Growth,

Vermicompost,

Yield and Zinc.

\section{Article Info}

Accepted:

04 July 2017

Available Online:

10 September 2017
A field experiment was conducted at College Farm, S. K. N. College of Agriculture, S. K. N. Agriculture University, Jobner, Rajasthan during 2016 to evaluate the influence of different vermicompost and zinc levels on growth and productivity of kharif season greengram. The experiment was laid out in a randomized block design, comprising vermicompost levels (control, VC @ $2.5 \mathrm{t}$ $\mathrm{ha}^{-1}$, VC@5.0 t ha ${ }^{-1}$ and VC @ $7.5 \mathrm{t} \mathrm{ha}^{-1}$ ) and zinc levels (control, Zn@2 kg ha ${ }^{1}$, Zn@4 kg ha ${ }^{-1}$ and Zn@6 kg ha ${ }^{-1}$ ), treatments replicated three times. The increasing levels of vermicompost and zinc increased the chlorophyll content, total number of nodules, effective number of nodules, root density, number of pods per plant, number of seeds per pod, test weight, grain and straw yield in greengram crop. However, the application of vermicompost @ $7.5 \mathrm{t} \mathrm{ha}^{-1}$ along with zinc @6 $\mathrm{kg} \mathrm{ha}{ }^{-1}$ found superior under loamy sand soil.

\section{Introduction}

Greengram [Vigna radiata $(\mathrm{L}$.$) ] is one of the$ important kharif pulse crop. It ranks third among all pulses grown in India after chickpea and pigeonpea. It contains 25 per cent protein. In India, total pulses are grown on 23.46 million ha area with a production of 19.27 million metric tonnes and an average productivity of $789 \mathrm{~kg} \mathrm{ha}^{-1}$ (DES, 2015). Greengram is a rainfed crop predominantly grown in kharif in the state of Rajasthan. In Rajasthan, greengram occupy 1.019 lakh ha area and production of 0.391 lakh tones with $384 \mathrm{~kg} \mathrm{ha}^{-1}$ productivity (DOA, 2014). One of the important reasons of low productivity is poor fertility of soil.
There is a great scope for increasing the production of greengram by applying organic manures (FYM/vermicompost) with balanced fertilization and maintaining soil fertility status. The use of vermicompost or other farm wastes to improve the physical, chemical and biological properties of the soil are salient features of efficient rainfed farming. The application of vermicompost not only adds plant nutrients (macro and micro) and growth regulators to the soil but also increases soil water retention, microbial population, humic substances of the soil, mineralization and release of nutrients (Manna and Biswas, 1996). A wide spread deficiency of $\mathrm{Zn}$ 
particularly in the light textured soils, having low organic carbon and alkaline reaction. In many parts of the country, $\mathrm{Zn}$ as a plant nutrient now stands third in importance next to nitrogen and phosphorus (Takkar and Randhawa, 1978). It is one of the essential micronutrient and plays important role in various enzymatic and physiological activities of the plant. It is also essential for photosynthesis and N-metabolism and important for the stability of cytoplasmic ribosome's, and cell division.

The efficiency of native micronutrients is further improved when these are used in conjunction with organic manures especially when the soils are belonging to arid and semiarid areas having light texture, low in organic carbon, low moisture retention and microbial activity. Hence, the present experiment was carried out to evaluate the influence of vermicompost and zinc on growth, yield attributes and yield of greengram.

\section{Materials and Methods}

A field experiment was conducted during kharif season of 2016 at College Farm, S.K.N. College of Agriculture, S.K.N. Agriculture University, Jobner, Rajasthan situated at $26.05^{\circ} \mathrm{N}$ latitude, $75.28^{\circ} \mathrm{E}$ longitude and at an altitude of $427 \mathrm{~m}$ above mean sea level. The soil was loamy sand. The soil had $\mathrm{pH}$ value of 8.10 , low in available nitrogen (136.60 kg N ha ${ }^{-1}$ ), medium in available phosphorus (17.50 $\mathrm{kg} \mathrm{P}_{2} \mathrm{O}_{5} \mathrm{ha}^{-1}$ ) and medium in potassium $\left(149.50 \mathrm{~kg} \mathrm{~K}_{2} \mathrm{O} \mathrm{ha}^{-1}\right)$. The experiment was laid out in a randomized block design, comprising vermicompost levels (control, VC@2.5 t ha ${ }^{-1}$, VC @ $5.0 \mathrm{t}$ $\mathrm{ha}^{-1}$ and VC@7.5 $\mathrm{t} \mathrm{ha}^{-1}$ ) and zinc levels (control, Zn@2 kg ha ${ }^{-1}, \mathrm{Zn} @ 4 \mathrm{~kg} \mathrm{ha}^{-1}$ and $\mathrm{Zn} @ 6 \mathrm{~kg} \mathrm{ha}^{-1}$ ), treatments replicated three times. Seed rate $20 \mathrm{~kg} \mathrm{ha}^{-1}$ of greengram variety 'SML- 668' was used in this study. The seeds were inoculated with rhizobium @ $20 \mathrm{gm} \mathrm{kg}^{-1}$ seed at the time of sowing. Whole amount of vermicompost as per treatment was broadcasted uniformly at the time of sowing and incorporated in the soil. The recommended dose of nitrogen $\left(20 \mathrm{~kg} \mathrm{ha}^{-1}\right)$ through urea, phosphorus $\left(30 \mathrm{~kg} \mathrm{ha}^{-1}\right)$ through DAP, potassium $\left(10 \mathrm{~kg} \mathrm{ha}^{-1}\right)$ through MOP and zinc through $\mathrm{ZnSO}_{4} .7 \mathrm{H}_{2} \mathrm{O}$ were applied as basal as per treatments.

\section{Results and Discussion}

\section{Effect of vermicompost}

Application of increasing levels of vermicompost significantly increased the growth attributes viz. chlorophyll content, total number of nodules, effective number of nodules and root density as well as yield attributes such as number of pods per plant, number of seeds per pod and test weight of greengram. The application of vermicompost also enhanced the grain and straw yield of greengram. The significant increase in grain and straw yield under the influence of vermicompost was largely a function of improved growth and yield attributes (Tables 1 and 2). The application of vermicompost @ $7.5 \mathrm{t} \mathrm{ha}^{-1}$ recorded the maximum value of these parameters. It is an established fact that vermicompost improves the physical and biological properties of soil including supply of almost all the essential plant nutrients for the growth and development of plants. Thus balanced nutrition under favourable environment might have helped in production of new tissues and development of new shoots. Another reason could be efficient and greater partitioning of metabolites and adequate location of nutrients to developing plant structures. As a result almost all growth and yield attributes resulted into significant improvement in yield of crop due to application of vermicompost. These results are in agreement with Tak (2003) in greengram, Sherin and Ahuja (2009) in clusterbean, Meena et al., (2014) in cowpea and Sharma (2016) in mustard. 
Table.1 Effect of vermicompost and zinc on growth attributes of greengram

\begin{tabular}{|c|c|c|c|c|c|}
\hline Treatments & $\begin{array}{c}\text { Chlorophyll } \\
\text { content at } \\
45 \text { DAS }\left(\mathrm{mg} \mathrm{g}^{-1}\right)\end{array}$ & $\begin{array}{c}\text { Total } \\
\text { number of } \\
\text { nodules }\end{array}$ & $\begin{array}{c}\text { Effective } \\
\text { number of } \\
\text { nodules }\end{array}$ & $\begin{array}{l}\text { Root density } \\
\text { at } 45 \text { DAS } \\
\left(\mathrm{cm} \mathrm{cm}^{-3}\right)\end{array}$ & $\begin{array}{l}\text { Root density } \\
\text { at harvest } \\
\left(\mathrm{cm} \mathrm{cm}^{-3}\right)\end{array}$ \\
\hline \multicolumn{6}{|c|}{ Vermicompost levels $\left(\mathrm{t} \mathrm{ha}^{-1}\right)$} \\
\hline Control $\left(\mathrm{VC}_{0}\right)$ & 3.08 & 28.08 & 26.68 & 4.87 & 6.56 \\
\hline $2.5\left(\mathrm{VC}_{2.5}\right)$ & 3.59 & 32.23 & 30.61 & 5.71 & 8.01 \\
\hline $5.0\left(\mathrm{VC}_{5.0}\right)$ & 4.08 & 35.30 & 33.35 & 6.84 & 8.38 \\
\hline $7.5\left(\mathrm{VC}_{7.5}\right)$ & 4.22 & 35.71 & 34.10 & 7.08 & 9.18 \\
\hline S.Em \pm & 0.06 & 0.30 & 0.28 & 0.04 & 0.05 \\
\hline $\mathrm{CD}(\mathrm{P}=0.05)$ & 0.17 & 0.87 & 0.81 & 0.12 & 0.15 \\
\hline \multicolumn{6}{|c|}{ Zinc levels (kg ha $\left.{ }^{-1}\right)$} \\
\hline Control $\left(\mathrm{Zn}_{0}\right)$ & 3.21 & 28.06 & 26.60 & 5.24 & 6.99 \\
\hline $2\left(\mathrm{Zn}_{2}\right)$ & 3.59 & 32.39 & 30.83 & 5.70 & 7.73 \\
\hline $4\left(\mathrm{Zn}_{4}\right)$ & 3.98 & 34.81 & 33.07 & 6.44 & 8.28 \\
\hline $6\left(\mathrm{Zn}_{6}\right)$ & 4.19 & 36.06 & 34.25 & 7.11 & 9.13 \\
\hline S.Em \pm & 0.06 & 0.30 & 0.28 & 0.04 & 0.05 \\
\hline $\mathrm{CD}(\mathrm{P}=0.05)$ & 0.17 & 0.87 & 0.81 & 0.12 & 0.15 \\
\hline
\end{tabular}


Table.2 Effect of vermicompost and zinc on yield attributes and yield of kharif greengram

\begin{tabular}{|c|c|c|c|c|c|}
\hline Treatments & $\begin{array}{c}\text { Number of pods } \\
\text { per plant }\end{array}$ & $\begin{array}{c}\text { Number of seeds } \\
\text { per pod }\end{array}$ & $\begin{array}{c}\text { Test weight } \\
\text { (g) }\end{array}$ & $\begin{array}{c}\text { Grain yield } \\
\left(\mathrm{kg} \mathrm{ha}^{-1}\right)\end{array}$ & $\begin{array}{c}\text { Straw yield } \\
\left(\mathrm{kg} \mathrm{ha}^{-1}\right)\end{array}$ \\
\hline \multicolumn{6}{|c|}{ Vermicompost levels $\left(\mathrm{t} \mathrm{ha}^{-1}\right)$} \\
\hline Control $\left(\mathrm{VC}_{0}\right)$ & 16.03 & 9.14 & 34.07 & 862.18 & 1977.72 \\
\hline $2.5\left(\mathrm{VC}_{2.5}\right)$ & 18.41 & 10.10 & 35.76 & 1095.26 & 2487.74 \\
\hline $5.0\left(\mathrm{VC}_{5.0}\right)$ & 20.30 & 11.07 & 38.65 & 1182.17 & 2839.47 \\
\hline $7.5\left(\mathrm{VC}_{7.5}\right)$ & 20.81 & 11.39 & 39.52 & 1197.27 & 2968.34 \\
\hline $\mathrm{S} . \mathrm{Em} \pm$ & 0.12 & 0.09 & 0.34 & 24.04 & 46.85 \\
\hline $\mathrm{CD}(\mathrm{P}=0.05)$ & 0.35 & 0.27 & 0.98 & 69.43 & 135.31 \\
\hline \multicolumn{6}{|c|}{ Zinc levels (kg ha $\left.{ }^{-1}\right)$} \\
\hline Control $\left(\mathrm{Zn}_{0}\right)$ & 17.21 & 9.62 & 34.12 & 868.08 & 1962.74 \\
\hline $2\left(\mathrm{Zn}_{2}\right)$ & 18.02 & 9.94 & 35.41 & 1098.03 & 2524.43 \\
\hline $4\left(\mathrm{Zn}_{4}\right)$ & 19.63 & 10.79 & 38.85 & 1178.67 & 2844.19 \\
\hline $6\left(\mathrm{Zn}_{6}\right)$ & 20.68 & 11.35 & 39.62 & 1192.10 & 2941.89 \\
\hline S.Em \pm & 0.12 & 0.09 & 0.34 & 24.04 & 46.85 \\
\hline $\mathrm{CD}(\mathrm{P}=0.05)$ & 0.35 & 0.27 & 0.98 & 69.43 & 135.31 \\
\hline
\end{tabular}

Table.3 Grain yield $\left(\mathrm{kg} \mathrm{ha}^{-1}\right)$ of greengram as influenced by interaction effect of vermicompost and zinc levels

\begin{tabular}{|c|c|c|c|c|}
\hline Treatments & $\mathrm{VC}_{0}$ & $\mathrm{VC}_{2.5}$ & $\mathrm{VC}_{5.0}$ & $\mathrm{VC}_{7.5}$ \\
\hline $\mathrm{Zn}_{0}$ & 729.20 & 946.22 & 998.43 & 798.45 \\
\hline $\mathrm{Zn}_{2}$ & 870.30 & 1096.70 & 1180.30 & 1244.81 \\
\hline $\mathrm{Zn}_{4}$ & 934.04 & 1173.67 & 1264.02 & 1342.95 \\
\hline $\mathrm{Zn}_{6}$ & 915.18 & 1164.46 & 1285.92 & 1402.85 \\
\hline S.Em \pm & \multicolumn{4}{|c|}{48.079} \\
\hline $\mathrm{CD}(\mathrm{P}=0.05)$ & \multicolumn{4}{|c|}{138.86} \\
\hline
\end{tabular}




\section{Effect of zinc}

The increasing levels of zinc significantly increased the growth parameters such as chlorophyll content, total number of nodules, effective number of nodules and root density as well as yield attributes number of pods per plant, number of seeds per pod and test weight of greengram. The grain and straw yield were also significantly increased by the application of zinc (Tables 1 and 2). The favourable influence of applied zinc on these growth parameters, yield attributes and yield may be ascribed to catalystic or stimulatory effect of zinc on most of the physiological and metabolic processes of the plant. It also helps in chlorophyll formation and plays an important role in nitrogen metabolism. Thus, the application of zinc in a soil deficient in its content, improved the overall growth and development of plant. The increase in these growth parameters and yield attributes ultimately results into the increased yields due to application of zinc were also reported by Jain (2007), Sharma and Abraham (2010), Dubey et al., (2013) and Jat et al., (2015) in different crops.

\section{Interaction effect}

A significant interactive effect of vermicompost and zinc on grain yield (Table 3) was also observed during present investigation. The increase in grain yield might be due to the fact that vermicompost and zinc had an additive effect and the experimental soil was deficient in nutrients viz., $\mathrm{Zn}$ and $\mathrm{Fe}$, supplementation of zinc and vermicompost incorporation improved the overall physical conditions of soil and increased water and nutrient retention in the root zone by reducing infiltration and percolation. Thus, improved the availability of both water and nutrients to plants for their better growth and development and ultimately increased these parameters of greengram.
These findings are in agreement with those of Sharma (2002) on wheat and Sharma et al., (2016) on mustard, also observed beneficial effect of vermicompost and zinc on yield.

On the basis of experimental finding, it can be concluded that, higher growth and yield of the kharif greengram crop (var. SML-668) can be obtained with the combined application of vermicompost@7.5 tha $\mathrm{ta}^{-1}+$ zinc@6 kg ha ${ }^{-1}$ under loamy sand soil of semi-arid region of Rajasthan.

\section{References}

DES, 2015. Commodity profit-pulses, Directorate of Economics and Statistics, Department of Agriculture and Cooperation and Department of Commerce, $3^{\text {rd }}$ Advance Estimates (April, 2014-March, 2015).

DOA, 2014. Rajasthan Agricultural StatisticsAt a glance 2013. Directorate of Agriculture, Statistical Cell, Rajasthan, Jaipur.

Dubey, S. K., Tripathi, S. K. and Singh, B. 2013. Effect of sulphur and zinc levels on growth, yield and quality of mustard [Brassica juncea (L.) Czern \& Coss.]. A Journal of Crop Science and Technology, 2: 2319-3395.

Jain, S., 2007. Effect of sulphur and zinc on growth and yield of mothbean [Vigna radiata (Jacq.) Marechal]. M.Sc. (Ag.) Thesis, Rajasthan Agricultural University, Bikaner.

Jat, G., Sharma, K. K. and Jat, N. K. 2015. Effect of FYM and mineral nutrients on physio-chemical properties of soil under mustard in western arid zone of India. Annals of Plant and Soil Research, 14:167-170.

Manna, M.C., and Biswas, A. K.1996. Yojana, P. 34.

Meena, J.S., Verma, H.P. and Pancholi, P. 2014. Effect of fertility levels and 
biofertilizers on yield, quality and economics of cowpea. Agriculture for Sustainable Development, 2: 162-164.

Sharma, J., 2016. Influence of Vermicompost and Different Nutrients on Performance of Indian Mustard [Brassica juncea (L.) Czern and Coss] in Typic Haplustepts. M. Sc. (Ag.) Thesis, Maharana Pratap Agricultural University and Technology, Udaipur.

Sharma, P., 2002. Effect of FYM and mineral nutrients on wheat (Triticum aestivum L.) grown under saline soil. M.Sc. (Ag.) Thesis, R.A.U., Campus, Jobner.

Sharma, V., and Abraham, T. 2010. Response of blackgram (Phaseolus mungo) to nitrogen, zinc and farmyard manure. Legume Research, 33:295-298.

Sharma. N. L., Singh. Y. and Duhan, B. S.
2016. Effect of integrated nutrient management on yield, quality and nutrients uptake by Indian mustard (Brassica juncea L.). Annals of Agriculture Biology Research, 19:660664.

Sherin, S., and Ahuja, S. 2009. Effect of organic and inorganic fertilizer on yield and yield attributes of clusterbean, Field Crop Abstract, 62: 596.

Tak, S., 2003. Effect of vermicompost and zinc on growth and yield of mungbean (Vigna radiata (L.) Wilczek). M.Sc. (Ag.), Thesis, Rajasthan Agricultural University, Bikaner.

Takkar, P.N., and Randhawa, N.S. 1978. Micronutrients in Indian Agriculture-A Review. Fertilizer News, 23: 8-26.

\section{How to cite this article:}

Anita Todawat, S.R. Sharma, Hansa Lakhran and Hemraj. 2017. Effect of Vermicompost and Zinc on Growth, Yield Attributes and Yield of Greengram [Vigna radiata (L.)] Under SemiArid Region of Rajasthan. Int.J.Curr.Microbiol.App.Sci. 6(9): 175-180. doi: https://doi.org/10.20546/ijcmas.2017.609.022 